\title{
ANALYSIS OF GROUNDNUT MARKETING IN THIRUVANNAMALAI DISTRICT OF TAMIL NADU
}

\author{
S. SELVANAYAKI ${ }^{1}$, K.MONISHA DEVI ${ }^{2}$, M.NIRMALA DEVI ${ }^{3} \&$ K.DIVYA $^{4}$ \\ ${ }^{1,4}$ Assistant Professor (ARM), Forest College and Research Institute, Mettupalayam \\ ${ }^{2}$ B.Sc. (Agri) Student, Agricultural College and Research Institute, Vazhavachanur, Thiruvannamalai \\ ${ }^{3}$ Associate Professor (Agrl Extn.), Department of Agrl Extension and Rural Sociology, TNAU, Coimbatore
}

\section{ABSTRACT}

Groundnut being a major oil seed crop of the country is also fetching much on the export market during the recent years. Present study has been taken up to analyse the marketing of ground nut in Thiruvannamalai District of Tamil Nadu, a major groundnut producing district of the state. Cost of cultivation and returns earned by the farmers were estimated as a part of the study. Data was collected from various intermediaries involved in the marketing channel. Marketing cost and margin earned by the intermediaries in different channels were worked out. Marketing efficiency for each channel was calculated using Sheperd's and Acharya Indices.

KEYWORDS: Marketing, Groundnut \& Crops

Received: Oct 02, 2020; Accepted: Oct 22, 2020; Published: Nov 21, 2020; Paper Id.: IJASROCT20202

\section{INTRODUCTION}

Groundnut is one of the major oil seed crop in India and is known as "King of oilseed crops", as well as "Wonder nut and poor men's cashew nut". In India cultivation of groundnut as an agricultural crop was initiated by the late $19^{\text {th }}$ century and gradually became the major groundnut producing country in the world. Presently, India shares $22 \%$ of world production.It is a major oil seed crop of Tamil Nadu,covering an area of 338300 hectares with a production of 783200 tonnes. Major Varieties cultivated by the TamilNadu farmers are JL24, Co 2,VRI 2,TMV 10,Co 3 along with some indigenous varieties. Present study has been taken up to identify various actors involved in the groundnut marketing in Thiruvannamalai district of Tamil Naduand estimate the marketing costs, marketing efficiency and value addition of groundnut under different channels.

\section{METHODOLOGY}

Thiruvannamalai district was purposively selected for the study as it is one of the major Groundnut producing districts in Tamil Nadu. Data was collected from a total of 142 sample respondents of which 60 each from groundnut cultivating farmers and consumers. Remaining were other intermediaries namely retailers, local traders, processors.

\section{Groundnut Marketing in Study Area}

Various value added products like oil, groundnut cake, chocolates, groundnut chikki etc., were produced from groundnut. It reaches the customer from producer by passing through various intermediaries. Different actor's role and value addition activities are presented in Table 1 
Table 1: Market Intermediaries and their role

\begin{tabular}{|c|c|c|}
\hline S.No & $\begin{array}{c}\text { Market } \\
\text { Intermediaries }\end{array}$ & Role \\
\hline 1 & Input suppliers & Selling of groundnut seeds, fertilizers and other farm inputs \\
\hline 2 & Producers & Procurement of inputs, Cultivation of groundnut, harvesting and loading \\
\hline 3 & Local traders & Procurement, repacking, transportation and bear product wastage risk. \\
\hline 4 & Processors & $\begin{array}{l}\text { Procurement from commission agents, processing, concrete production and } \\
\text { sales. }\end{array}$ \\
\hline 5 & Wholesalers & $\begin{array}{l}\text { Procurement from commission agents, packing, transportation and } \\
\text { wholesale to markets }\end{array}$ \\
\hline 6 & Retailers & $\begin{array}{l}\text { Purchasing quality produces in limited quantity, value addition activities } \\
\text { such as making eatable items, bear product wastage, transport cost and } \\
\text { final sales to customer. }\end{array}$ \\
\hline 7 & Consumers & $\begin{array}{l}\text { Buying the groundnut products from retailers, local traders for domestic } \\
\text { purpose and work purpose }\end{array}$ \\
\hline
\end{tabular}

\section{Price Spread Analysis}

Information was collected from individual farmers and traders on various types of cost incurred by them including transportation, weighing, loading and unloading, packing, storage, spoilage and other expenses. In the process of marketing groundnut, the difference in price paid by the consumer and that received by the groundnut producer for an equivalent quantity is the Price Spread of groundnut. Profit of various market functionaries involved in moving the produce from the initial point of production till it reached the ultimate consumer were recorded. Sum-of-average gross margin method was used in estimation of price spread.

\section{Farmers Share in Consumer Rupee}

Farmers share in consumer rupee was calculated using the following formula.

$$
\mathrm{Fs}=(\mathrm{Fp} / \mathrm{Cp}) \times 100
$$

Where,

Fs $=$ Farmers share in consumer rupee (percentage)

$\mathrm{Fp}=$ Farmers price

$\mathrm{Cp}=$ Consumers price

\section{Marketing Efficiency}

For calculating marketing margins, Shepherd's formula and Acharya'sIndex weredescending order. Attribute with the highest mean value was assigned first rank and the remaining attributes were arranged in a similar manner. 


\section{RESULTS AND DISCUSSIONS}

\section{Calculating Cost and Required Investments of Groundnut Production}

In order to understand the economics of groundnut production, the cost of cultivation for groundnut was estimated and discussed in Table 2. Cost of cultivation was calculated on per acre basis.

\section{Cost of Cultivation}

Table 2: Cost involved in groundnut cultivation

\begin{tabular}{|c|c|c|c|}
\hline S. No & Particulars & Cost (Rs./ acre) & Percent \\
\hline 1 & $\begin{array}{l}\text { Land preparation } \\
\text { a)Ploughing Expenses }-2 \text { times/acre } \\
\text { Rs. } 1000 \text { / time }\end{array}$ & 2000 & 12.11 \\
\hline 2 & Seed cost - 2 bag / acre @ Rs.2200 & 4400 & 26.63 \\
\hline 3 & $\begin{array}{l}\text { Sowing } \\
\text { Machine sowing - } 1 \text { hr/acre @Rs.1200 }\end{array}$ & 1200 & 7.26 \\
\hline 4 & $\begin{array}{l}\text { Manures and fertilizers } \\
\text { FYM = } 2 \text { tipper / acre @ Rs.3000 } \\
\text { NPK: 25:50:75 } \\
\text { DAP - 1 bag/acre @ Rs.1300 } \\
\text { Complex - } 1 \text { bag @ Rs.400 } \\
\text { Gypsum - } 1 \text { bag/acre @ Rs.250 }\end{array}$ & 4950 & 29.96 \\
\hline 5 & $\begin{array}{l}\text { Weeding } \& \text { Earthing up } \\
\text { Number of weeding = } 15 \text { labours @ Rs. } 150 \text { per labour }\end{array}$ & 2250 & 13.62 \\
\hline 6 & $\begin{array}{l}\text { Plant protection } \\
\text { Number of spraying-2 times } \\
\text { (Monocrotophos 36 SL = Rs.1000 } \\
\text { Spraying cost-6 tank /acre Rs.30/tank@ Rs.180 }\end{array}$ & 1180 & 7.14 \\
\hline 7 & $\begin{array}{l}\text { Irrigation charges } \\
\text { Number of irrigation }=6 \text { irrigations/ Season/acre }\end{array}$ & - & - \\
\hline 8 & $\begin{array}{l}\text { Harvesting } \\
\text { No. of. Labours for Harvesting=15 labours /acre } \\
\text { Loading \& Unloading = Rs. 15/bag / Labour } \\
\quad=18 \text { bag /acre @ Rs } 270 \\
\text { Gunny bag cost=Rs.15/bag @Rs.270 }\end{array}$ & 540 & 3.26 \\
\hline & Total cost & 16,520 & 100 \\
\hline
\end{tabular}

The total cost incurred by the sample farmers for cultivation of groundnut in the study area was Rs.16,520 / acre of which Manure and Fertilizers (29.96 per cent) took a major share followed by the seed cost (26.63 per cent) 


\section{Returns in Groundnut Cultivation}

Kanimozhi (2013) in her study estimated the total cost and returns in order to predict the profit earned by farmersand a similar methodology is adopted in the present study as well.The cost and returns for the sample farmers in groundnut cultivation was worked out and the results are presented in Table 3.

Table 3: Returns in groundnut cultivation in the study area

\begin{tabular}{|l|l|l|}
\hline $\begin{array}{c}\text { S. } \\
\text { No }\end{array}$ & \multicolumn{1}{|c|}{ Particulars } & \multicolumn{1}{c|}{ Amount } \\
\hline 1 & $\begin{array}{l}\text { Quantity produced (in } \mathrm{kg}) / \\
\text { acre }\end{array}$ & \multicolumn{1}{c|}{900} \\
\hline 2 & Price received (Rs/Kg) & 25.00 \\
\hline 3 & Gross income (in $\mathrm{Rs})$ & 22500 \\
\hline 4 & Net income (in Rs) & 5980 \\
\hline 5 & Cost of production (Rs/kg) & 18.35 \\
\hline 6 & Net returns (Rs/kg) & 6.64 \\
\hline
\end{tabular}

It could be seen that the cost of production of Groundnut per $\mathrm{kg}$ was Rs. $18.35 / \mathrm{kg}$ and the net income was observed to be Rs. 5,980 / acre. The farmers received Rs. 6.64 as net returns per kg of groundnut.

\section{Price Spread Analysis}

Kumaravel (2005) in his study used price spread analysis in order to identify the difference in price along the value chain. In order to understand the value chain practices and problems in marketing of groundnut value chain through which it was marketed channels were different was traced and the price spread was worked out. The price spread across the four different channels is presented in Figure 1.

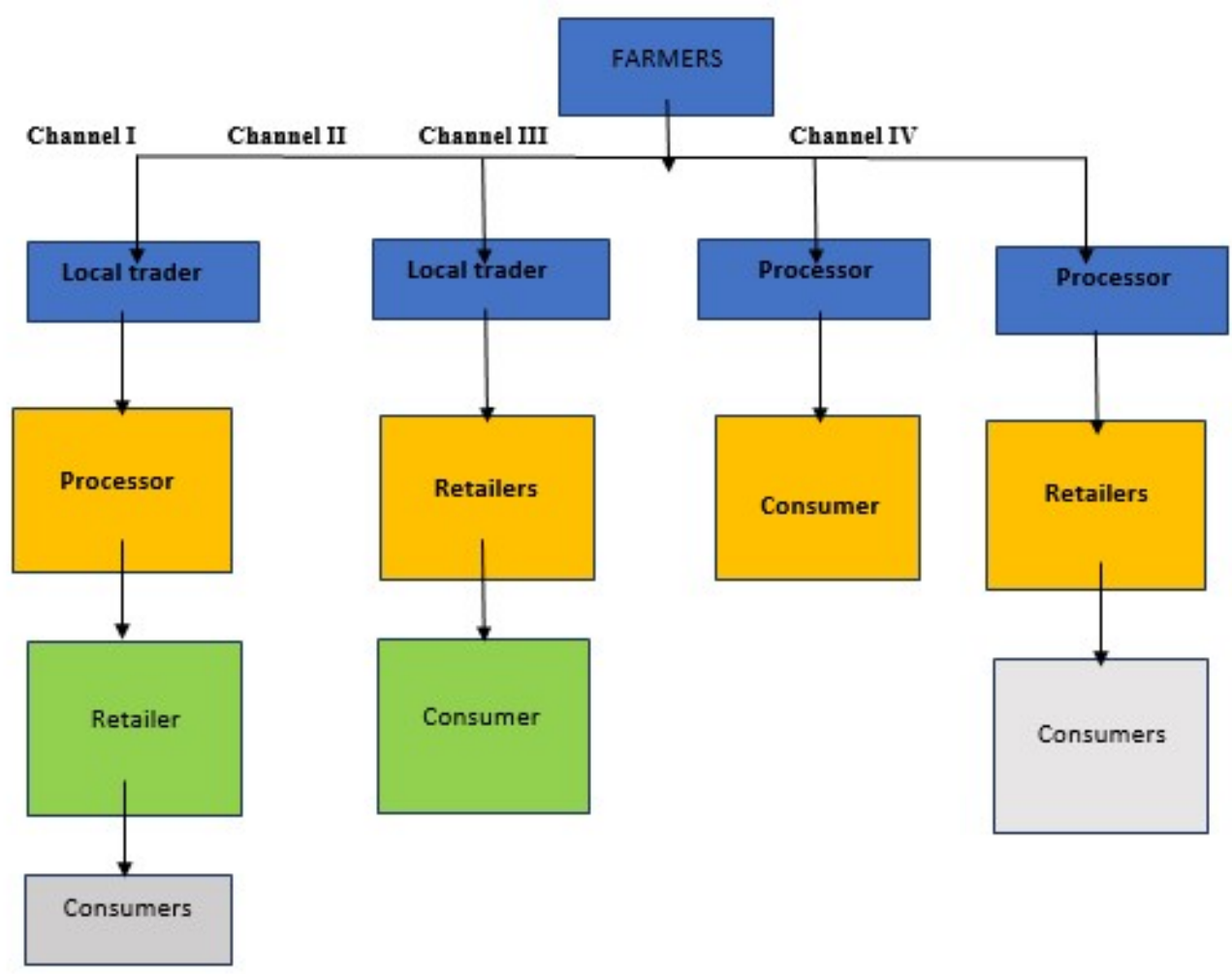

Figure 1: Groundnut marketing - Channel mapping 
Flow of groundnut through four different channel namely channel I, channel II, channel III and channel IV with various intermediaries involved in moving of groundnut to different market levels are presented in Figure 1. In the channel I, the groundnut was procured by local traders from the farmers and the local traders at Thandrampet and Thiruvannamalai sold it to processors and the processor in turn handover the groundnut seeds to retailers to reach the consumers . Whereas in channel II, the groundnut marketing startedfrom farmers to local traders and then to retailer and then it reached the consumers. In the channel III, the processors after procurement of the groundnut seeds from the farmers sold it to consumers. The channel IV comprised of farmers, processor, retailers and consumers.

Table 4: Price spread across the channel I

Farmers $\longrightarrow$ Local traders $\longrightarrow$ Processor $\longrightarrow$ Retailer $\longrightarrow$ Consumer

\begin{tabular}{|c|c|c|c|}
\hline S.No & Particulars & Amount(Rs per kg) & $\begin{array}{l}\text { Percentage to } \\
\text { consumer price }\end{array}$ \\
\hline \multirow[t]{4}{*}{1.} & FARMERS & & \\
\hline & Gross price received by the farmer & 27 & 79.41 \\
\hline & $\begin{array}{l}\text { Marketing cost (loading and transport } \\
\text { @ Rs } 2 / \mathrm{Kg} \text { ) }\end{array}$ & 2 & 5.88 \\
\hline & Net price received by the farmer & 25 & 73.52 \\
\hline \multirow[t]{5}{*}{2.} & Local traders & & \\
\hline & Price paid by the local traders & 27 & 79.41 \\
\hline & Marketing cost@ Rs.1/Kg & 1 & 2.94 \\
\hline & Profitmargin@Rs.2 / Kg & 2 & 5.8 \\
\hline & Price received by the local trader & 28 & 82.35 \\
\hline \multirow[t]{5}{*}{3} & Processor & & \\
\hline & Price paid by the processor & 28 & 82.35 \\
\hline & Marketing cost@ Rs.2 / kg & 2 & 5.88 \\
\hline & Profit margin@Rs.5 / kg & 5 & 14.7 \\
\hline & Price received by the processor & 31 & 91.17 \\
\hline \multirow[t]{3}{*}{4.} & Retailers & & \\
\hline & Price paid by the retailers & 31 & 91.17 \\
\hline & Marketing cost@ Rs. 2/Kg & 2 & 5.88 \\
\hline
\end{tabular}




\begin{tabular}{|l|l|l|l|}
\hline & Profit margin @Rs 5 per kg & 5 & 14.7 \\
\hline $\mathbf{5}$ & Price received by the retailer & 34 & 100 \\
\hline & Consumer & 34 & 100 \\
\hline & Price paid by the consumer & 7 & 20.5 \\
\hline & $\begin{array}{l}\text { Price spread @ Rs.27 / kg } \\
\text { cent) }\end{array}$ & $\mathbf{7 3 . 5 2}$ & \\
\hline
\end{tabular}

After the farmers sold the produce to the local traders the farmers have received only Rs.25/kg and the local traders received Rs.28/ kg from processors, so the local traders received a profit of Rs. 3/ kg. Processors sold their produce to the retailers at the rate of Rs. $31 / \mathrm{kg}$ and getting the profit margin of Rs.5/ kg. Finally, retailers sold the produce to the customers at Rs.34 / kg in the channel I. Price spread was observed to be Rs.7 / kg and farmers share in consumer's price was 73.5 per cent.

Table 5: Price spread across the channel II

Farmers $\longrightarrow$ Local trader $\longrightarrow$ Retailer $\longrightarrow$ Consumer

\begin{tabular}{|c|c|c|c|}
\hline S.No & Particulars & $\begin{array}{l}\text { Amount(Rs per } \\
\text { kg) }\end{array}$ & Percentage to consumer price \\
\hline \multirow[t]{4}{*}{1.} & FARMERS & & \\
\hline & Gross price received by the farmer & 27 & 87.09 \\
\hline & $\begin{array}{c}\text { Marketing cost (loading and transport } \\
\text { @Rs } 2 / \mathrm{Kg} \text { ) }\end{array}$ & 2 & 6.45 \\
\hline & Net price received by the farmer & 25 & 80.64 \\
\hline \multirow[t]{5}{*}{2} & Local trader & & \\
\hline & Price paid by the local trader & 27 & 87.09 \\
\hline & Marketing cost@Rs.1/Kg & 1 & 3.22 \\
\hline & Profit margin@Rs 2 / Kg & 2 & 6.45 \\
\hline & Price received by the local trader & 28 & 90.32 \\
\hline \multirow[t]{4}{*}{3.} & Retailer & & \\
\hline & Price paid by the retailer & 28 & 90.32 \\
\hline & Marketing cost@Rs.2 / kg & 2 & 6.45 \\
\hline & Profit margin@Rs.5/kg & 5 & 16.12 \\
\hline
\end{tabular}




\begin{tabular}{|c|c|c|c|}
\hline & Price received by the retailer & 31 & 100 \\
\hline $\mathbf{4}$ & Consumer & 31 & 100 \\
\hline & Price paid by the consumer & 4 & 12.90 \\
& Price spread @ Rs.27 / kg & & $\mathbf{8 0 . 6 4}$ \\
\hline & $\begin{array}{c}\text { Farmers share in total price (in per } \\
\text { cent) }\end{array}$ & & \\
\hline
\end{tabular}

From Table 5 it could be inferred that the farmers received Rs.27/ kg from local traders and the local traders gets Rs. $28 / \mathrm{kg}$ from retailers so the local traders received a profit of Rs. $2 / \mathrm{kg}$. Finally, retailer sold the produce to the consumer at Rs. 31/ kg in the channel II. Price spread was observed to be Rs. $4 / \mathrm{kg}$ and the farmers share in consumers' price was 80.64 per cent.

Table 6: Price spread across the channel III

Farmers $\longrightarrow$ Processor $\longrightarrow$ Consumer

\begin{tabular}{|c|c|c|c|}
\hline S.No & Particulars & Amount (Rs per kg) & $\begin{array}{l}\text { Percentage to consumer } \\
\text { price }\end{array}$ \\
\hline \multirow[t]{4}{*}{1.} & FARMERS & & \\
\hline & Gross price received by the farmer & 27 & 84.37 \\
\hline & $\begin{array}{l}\text { Marketing cost (loading and transport } \\
\text { @ Rs } 2 / \mathrm{Kg} \text { ) }\end{array}$ & 2 & 6.25 \\
\hline & Net price received by the farmer & 25 & 78.13 \\
\hline \multirow[t]{5}{*}{2.} & Processor & & \\
\hline & Price paid by the local trader & 27 & 84.37 \\
\hline & Marketing cost@Rs. 5 / Kg & 5 & 15.63 \\
\hline & Profit margin@ Rs 10 / Kg & 10 & 31.25 \\
\hline & Price received by the local trader & 32 & 100 \\
\hline \multirow[t]{4}{*}{3.} & Consumer & & \\
\hline & Price paid by the consumer & 32 & 100 \\
\hline & Price spread@ Rs. 27 / kg & 5 & 15.6 \\
\hline & $\begin{array}{l}\text { Farmers share in total price (in per } \\
\text { cent) }\end{array}$ & \multicolumn{2}{|l|}{78.13} \\
\hline
\end{tabular}

In this channel, farmers have receive Rs. $27 / \mathrm{kg}$ and the processors received the produce at Rs. $32 / \mathrm{kg}$ from the farmers and the price spread was observed to be Rs.3/ kg. 
Table 7: Price spread across the channel IV

Farmers $\longrightarrow$ Processor $\longrightarrow$ Retailers $\longrightarrow$ Consumers

\begin{tabular}{|c|c|c|c|}
\hline S. No & Particulars & Amount (Rs per kg) & $\begin{array}{l}\text { Percentage to consumer } \\
\text { price }\end{array}$ \\
\hline \multirow[t]{4}{*}{1.} & FARMERS & & \\
\hline & Gross price received by the farmer & 27 & 79.41 \\
\hline & $\begin{array}{l}\text { Marketing cost (loading and transport @ } \\
\text { Rs. } 2 \text { / Kg) }\end{array}$ & 2 & 5.88 \\
\hline & Net price received by the farmer & 25 & 75.75 \\
\hline \multirow[t]{5}{*}{2.} & Processor & & \\
\hline & Price paid by the processor & 27 & 81.8 \\
\hline & Marketing cost@ Rs.2 / Kg & 2 & 6.06 \\
\hline & Profit margin@ Rs 5 / Kg & 5 & 15.15 \\
\hline & Price received by the processor & 30 & 90.9 \\
\hline \multirow[t]{5}{*}{3.} & Retailers & & \\
\hline & Price paid by the retailers & 30 & 90.9 \\
\hline & Marketing cost@ Rs. 2/Kg & 2 & 6.06 \\
\hline & Profit margin@Rs. 5 / kg & 5 & 15.15 \\
\hline & Price received by the retailer & 33 & 100 \\
\hline \multirow[t]{4}{*}{5} & Consumer & & \\
\hline & Price paid by the consumer & 33 & 100.00 \\
\hline & Price spread@Rs.27 / kg & 6 & 18.18 \\
\hline & $\begin{array}{l}\text { Farmers share in consumer's rupee (in per } \\
\text { cent) }\end{array}$ & \multicolumn{2}{|l|}{75.75} \\
\hline
\end{tabular}

Farmers have received only Rs.27/ kg from processor and the processor gets Rs. 30 / kg from retailers, so the processors received a profit of Rs. $5 / \mathrm{kg}$. The retailers sold their produce at the rate of Rs. $33 / \mathrm{kg}$. From the table the price spread was observed to be Rs. 6/ kg and farmers share in consumer's price was 75.75 per cent.

Price spread analysis of four different marketing channels is presented in Tables 4,5,6 and 7 respectively. It could be concluded that various costs involved and marketing efficiency of different channels were identified through farmers share in consumer rupee. The price received by the farmers was considered as Rs. $27 / \mathrm{kg}$. The farmers share was high in the channel II $(80.64 \%)$.

\section{Marketing Efficiency of Different Channels}

Marketing efficiency is a measure of market performance. The movement of goods from producer to ultimate consumer at the lowest possible cost consistent with the provision of service desired by the consumers is termed as 
efficient marketing. The marketing efficiency of different channels was estimated using the two following methods.

1. Shepherd method

2. Acharya's approach

More than one method was used to check the accuracy of efficiency. The results of marketing efficiency are presented in Table 8

Table 8: Marketing efficiency of different channels

\begin{tabular}{|l|l|l|l|l|l|}
\hline S. No & \multicolumn{1}{|c|}{ Particulars (in Rs) } & $\begin{array}{c}\text { Channel } \\
\text { I }\end{array}$ & $\begin{array}{c}\text { Channel } \\
\text { II }\end{array}$ & $\begin{array}{c}\text { Channel } \\
\text { III }\end{array}$ & $\begin{array}{c}\text { Channel } \\
\text { IV }\end{array}$ \\
\hline I & Value of goods sold & 34 & 31 & 32 & 34 \\
\hline II & Total marketing cost & 7 & 5 & 7 & 6 \\
\hline A & $\begin{array}{l}\text { Shepherd's Marketing Efficiency[ } \\
\text { (i/ii)-1] }\end{array}$ & $\mathbf{3 . 9}$ & $\mathbf{5 . 2}$ & $\mathbf{3 . 5}$ & $\mathbf{4 . 6 6}$ \\
\hline III & Total marketing cost & 7 & 5 & 7 & 6 \\
\hline IV & Net marketing margin & 12 & 7 & 10 & 10 \\
\hline V & $\begin{array}{l}\text { Net Price received by the farmers } \\
\text { B }\end{array}$ & 25 & 25 & 25 & 25 \\
\hline $\begin{array}{l}\text { Acharya's marketing Efficiency I (iii+iv)] } \\
\text { v }\end{array}$ & $\mathbf{1 . 3}$ & $\mathbf{2 . 0 8}$ & $\mathbf{1 . 5}$ & $\mathbf{1 . 5 6}$ \\
\hline
\end{tabular}

It could be inferred that the channel II namely Farmers- local trader - retailers - consumers was the efficient as it had highest marketing efficiency because they had less number of intermediaries and the farmers share on consumer's price was high than the other channels.

\section{CONCLUSIONS}

It was inferred from the study that the cost of cultivation of groundnut in the study area was Rs.16,520 / acre with maximum share of around 30 per cent for Manure and Fertilizers followed by the seed cost (26.63 per cent). The cost of production per kg was Rs. 18.35 and the farmers received Rs. 6.64 as net returns per kg. Four major channels were identified of which farmers share was high in the channel II namely Farmers- local trader - retailers - consumers (80.64\%). It could be inferred that the Channel II was more efficient and had highest marketing efficiency than the other channels.

\section{REFERENCES}

1. Vinutha, D. N., et al. "Genetic correlation and path-coefficient analysis of yield and its components in groundnut (Arachis hypogaea L.) genotypes." International Journal of Agricultural Science and Research (IJASR) 5.5 (2015): 89-94.

2. CHAUDHARY, ANAM. "A STUDY OF MARKET ANALYSIS OF PESTICIDES." International Journal of Agricultural Science and Research (IJASR)8.6, Dec 2018, 7-14 
3. Suseela, K., and M. Chandrasekaran. "Crop Diversification in Andhra Pradesh-Regional and State Level Analysis." International Journal of Agricultural Science and Research 6.3 (2016): 187-193.

4. Chhipa, Megha Kumari, Sandhya Srivastav, and Neetee Mehta. "Suitability of Dyes From Peanut Pod on Different Fabrics Using Copper Sulphate Mordanting Agent." International Journal of Textile and Fashion Technology (IJTFT) 7.1 (2017): 110 .

5. Pawariya, Vikash, RC SHARMA, and BK SHARMA. "Impact of Ground Water Markets in Changing Cropping Pattern in Rajasthan State." International Journal of Agricultural Science and Research (IJASR) 7.4 (2017): 103-118. 